\title{
Bribery: \\ What Do Australian Managers Know and What Do They Do?
}

\author{
Michael Segon and Chris Booth \\ RMIT University, Australia
}

\begin{abstract}
The recent conviction and gaoling of former Rio Tinto executive Stern $\mathrm{Hu}$ and as well as a further 18 Australian citizens facing charges in relation to "fraud and other economic crimes raises a number of questions regarding ethical business practice. A key issue that should be considered is whether Australian businesses are as ethical and transparent as the current high ranking in the Transparency International corruption index tends to suggest.

This paper reviews literature pertaining to the normalisation of corrupt practices and the extent to which organisational members and managers are aware of and take action to report such practices. The paper will also present the findings of a survey of over 100 practicing managers that identifies whether they are aware of unethical practices and what they would do if they were to offer or receive an offer to engage in unethical practices. The survey focuses on a major corrupt practice, namely bribery. It also considers the reaction of managers to the request or order of a senior manager to engage in unethical practices inclusive of bribery. Conclusions will then be drawn regarding the extent of normalisation of corruption in Australian organisations.
\end{abstract}

\section{Keywords}

Business Ethics, Management, Bribery and Corruption, Cross Culture.

\section{Introduction}

Corporations operating in foreign countries, particularly developing economies, are frequently presented with the challenges of managing business processes that are not transparent and characterised by the use of facilitation payments. This highlights the importance of understanding what bribery and corruption actually involves, as they are interpreted differently around the globe. As stated above the recent case of Stern $\mathrm{Hu}$ and his Rio Tinto colleagues charged and found guilty of bribery charges under Chinese national law has given many transnational corporations operating in China and elsewhere pause to think (Lewis, 2006; Moran, Harris and Moran, 2007) not only about issues of standards and ethics in business practice in overseas locations but also to reconsider the critical subtleties in cultural mores as well as understanding the impacts of choices and actions in cross cultural contexts.

As Donaldson and Dunfee (1999a p. 47) noted "the importance of cultural differences to business are highlighted by Kluckhorn, Hofstede, Hamden-Turner and Trompenaars, yet the ethical implications remain largely unexplored". For some the concept of bribery, to get goods through customs for example, is no different to that of tipping for better service in a restaurant whilst for others the two actions are very different. Gift giving also presents many challenges for organisations and managers. From one perspective it can clearly be seen as an act of reciprocity, yet Westerners often misconstrue it as bribery. Guanxi or gift giving appears to be an important element of Asian cultures (Davies, 
Leung, Luk and Wong, 1995). As a practice guanxi can be seen as a form of relationship investment that if cultivated well can 'uplift interactions' between businesses (D'Souza 2003, p. 27).

This paper considers the concept of bribery as a component of corrupt business practice and through a survey evaluates the attitudes of a diverse group of practising business managers in the Asia Pacific region towards bribery, corrupt business practice and ethical business decision making. The paper presents a literature review establishing definitions of bribery and corruption, considerations of corruption as a global phenomenon affecting many countries both developing and developed, and considerations of how corruption may become a normalised practice in organisations and business manager activities.

\subsection{Literature Review}

The review of literature considers discussions on the overarching concept of corruption and also bribery as a key attribute of corrupt practice. The review firstly discusses the concept of corruption in developing economies, moving through potential causes of corruption and finally consideration of bribery issues in cultural contexts.

\subsection{Definitions of corruption and bribery}

There has been considerable debate on the difficulty in defining the term corruption, as it is a multifaceted concept which figures across a wide landscape of contexts inclusive of society, law, politics, ethics, national culture, and in business, organizational contexts, economics and finance (Dion, 2010; Halter, Coutinho de Arruda and Halter, 2009; Kayes, D,.C. 2006; Von Aleman, 2004). Nevertheless a broad definition is needed to proceed with any purposeful analysis and discussion.

According to Transparency International (TI) (2011a) 'Corruption is operationally defined as the abuse of entrusted power for private gain.' In its definition TI focuses predominantly on bribery as a core consideration within the global context of corruption but also includes considerations of kickbacks in public procurement and embezzlement of public funds (Transparency International, 2011b).

Lindgreen (2004) also provides a broad based definition of corruption 'as individuals or enterprises misusing public resources for power and/or political gains through abusing public officials whose behaviour deviates from the rules of conduct (see for example Heidenheimer et al., 1989; Huntington, 1968; Khan, 1996; Nye, 1967; Poole-Robb and Bailey, 2002).' Lindgreen's definition precludes commercial corruption in terms of private to private sector corruption which Hess (2009) has identified as one of two well known national and international legislation exceptions regarding corruption. The other exception according to Hess (2009) relates to facilitation payments made to expedite lawful services and activities. Transparency International (2011a) however identifies a facilitation payment as 'according to the rule' corruption wherein the bribe is paid to receive preferential treatment for services or actions that the bribe recipient is required to do by law. Where a bribe is paid to secure service or action that the bribe recipient is prohibited of providing under law is classified as 'against the rule' corruption by Transparency International (2011a).

Osbourne (1997) classifies corruption into three groups: bureaucratic corruption where officials take bribes; political corruption where politicians take bribes; and grand corruption signifying misuse of public power by heads of states for private pecuniary benefit. The bribes are usually given by organisations to influence the outcome of government contracts, allocation of monetary benefits (tax evasion, subsidies, etc.), speed up government's granting of permits to carry out legal activities and influence outcomes of legal and regulatory processes (Batabyal and Yoo, 2007; Carmichael, 1995; Gray and Kaufmann, 1998; Kaufmann and Wei, 1998; Kaufmann, 1997).

For the purposes of this article the Transparency International's (2011a) definition of corruption as, the abuse of entrusted power for private gain, is applied. This broad definition does not preclude private to private sector corruption as indicated by Hess (2009) nor facilitation payments defined as 
'according to the rule' corruption (Transparency International, 2011a). Moreover Transparency International (TI) considers bribery to be the key component of corruption and for the purposes of the present article discussion of corruption predominantly deals with issues related to bribery in national and international contexts. This is in line with Dunfee's focus on 'coarse corruption' (i.e. bribery) in a number of his key writings (Hess and Dunfee, 2000; Donaldson and Dunfee, 1999b).

\subsection{The nature of bribery}

One of the key attributes of a corrupt culture relates to bribery. Transparency International (2009) not only maintains a Corruption Perception Index (CPI) but also a Bribe Payer's Index (BPI). Along with embezzlement and fraud, bribery stands as a key form of unethical practice in considering corrupt business practice, (Goudie and Stasavage, 1998; McEwan, 2001). According to Shaw and Barry (1998, p 354), "Bribery is an obvious conflict of interest. A bribe is remuneration for the performance of an act that's inconsistent with the work contract or the nature of work one has been hired to perform. The remuneration can be money, gifts, entertainment, or preferential treatment." McEwan (2001) defines bribery as illegal or improper benefit gained in exchange for money or other payment that is valued.

Apke (2001) defines bribery as gaining improper advantage for business activities such as gaining orders, applications for regulatory permits, customs, taxation concessions and judicial and legislative rulings. It is also clear that bribery and corruption share a conceptual synergy in definition in terms of unethical behaviour to derive personal gain. Ampratwum $(2008$, p.76) states that corruption is 'usually defined as the transgression of formal rules governing the allocation of public resources by officials in response to offers of financial gain or political support'. Alatas $(1999$, p.6) concurs citing Wertheim's (1965) description of corruption as 'a public servant who accepts gifts bestowed by a private person with the object of inducing him to give special consideration to the interests of the donor'. He also suggests that extortion, or the expectation or demand for gifts or favours in the execution of public duty also constitutes a form of corruption.

\subsection{Corruption: Developed and developing economies}

There is general agreement that corruption exists in most societies but at different levels of severity and impact (Transparency International, 2009). Furthermore most developing and transition economies are more prone to corruption than developed ones (Goldsmith, 1995; Ksenia 2008). This assertion is supported to some extent by Transparency International (2009) which argues that national economies that are open and integrated with world markets, combined with robust political, social and legal systems appear less prone to corruption than those which are not. The 2009 Transparency International (TI) corruption index also lends support with results for the three least corrupt countries identified as New Zealand, Denmark and Singapore all considered as developed economies with robust political-social legal systems, whilst the most corrupt were identified as Myanmar, Afghanistan and Somalia (Transparency International, 2009).

Within Australia corruption and bribery is recognized as existing and becoming an increasing problem (KPMG, 2008). This is despite the fact that Australia scored better than all members of the G8 and better than the majority of OECD countries in the Transparency International indexes and has done so consistently for a number of years (Transparency International, 2006, 2007, 2010). According to the most recent Transparency International index, Australia ranks as equal $8^{\text {th }}$ out of the 180 countries with a score of 8.7 out of 10 (Transparency International, 2010). However, recent research by Bowman and Gilligan (2007) found that a substantial majority of respondents agreed that corruption was damaging, inevitable, and increasing in Australia.

\subsection{Potential causes of corruption}

The World Bank (1997) identifies the causes of corruption as poorly designed economic policies, underdeveloped civil society, low levels of education, and weak accountability of public institutions. These are all characteristics of developing and transitioning economies and perhaps provide insight 
into why they experience corruption (Ksenia, 2008). Gray and Kaufmann (1998) and Alatas (1999) assert that corruption is widespread most amongst developing economies which are typically characterised by an ineffective regulatory system, a high degree of internal political competition, where individual civil liberties and political freedoms are restricted, the majority of the population are in lower socio-economic brackets and poverty is common and accountability is weak. Other factors influencing corruption include the standard of education, income per capita, low and uneven economic growth along with the level of competition and greed (Beets, 2004; Davis and Ruhe, 2003; Feng, 2000; Oskooee, Goswami, \& Gour, 2005; Welsch, 2004). Corruption often remains due to the fact it has become institutionalised and essentially becomes accepted (United Nations Development Programme, 2008).

Evidence suggests that factors such as international trade barriers, limited freedom of the press along with the policies applied across the banking sector can cause a higher degree of corruption (Mauro, 1995).. Andenas (1995) argues that significant structural changes to political and economic systems can also be a major contributing factor to the prevalence of corruption. He notes that this appears to be a major problem in former communist countries whose economies are in transition, largely due to an absence of experience with the co-existence of a private and public sector. The privatisation or transfer of public enterprises or public assets to the competitive private sector which introduces competition to an inexperienced sector can also stimulate bribery..

A large proportion of the civil service in these underdeveloped or transitioning economies are significantly underpaid relative to the economic growth and wealth generation that often occurs due to the liberalisation of the economy and the privatisation of assets. 'Underpaid public servants see a chance to take part in the conspicuous consumption becoming a part of their societies, or at least to maintain living standards in a period where the purchasing power of public sector salaries is radically reduced in relative terms (Andenas, 1995 p. 60). However, the issue of potential for corruption is not limited to developing countries alone. Ampratwum (2008) notes that US studies show increases in civil service wages do not necessarily result in a reduction of corruption. Therefore, other influences are very powerful. The recent UK Politicians expense claims scandal presented a series of corrupt practices by several politicians from both sides of politics in that country (MacDonald and Fidler, 2009).

\subsection{The normalisation of corruption in organizations as managerial practice}

Much literature exists relating the political and economical characteristics of countries to the primary forces driving corruption. It is important to note that corporations also 'choose' to pay bribes to do business, which contributes to the normalisation of corruption in these countries. Carmichael (1995) identifies three reasons why corporations may take part in such forms of corruption:

1. They perceive bribery as the business norm in the country in order to get successful business transactions.

2. Even though they may identify the act (bribery) as morally wrong, they do it because other corporations also do it.

3. Corporations desperate for business and under pressure may choose unethical practices to obtain business for financial success.

Ashford and Anand (2003) lay out a process for the normalization of corruption behaviour within an organization. They assume that all organizations have the potential for corrupt or unethical practices as opportunities exist both internally and externally which if accepted can result in the normalisation of the practice for managers. They define normalization as behaviour that has become embedded and internalized by organizational members, who see it as permissible and even desirable behaviour. These practices are then passed on to successive generations of members under the guise of normal practice. The authors identify some factors, such as culture and organizational memory within an organisational context, that can encourage their proposed process of an initial corrupt act, leading to embedding, and repetition,. They primarily focus on how an environment develops that promotes 
corruption, once the acts have already been carried out, not what inspires the corrupt acts in the first place. Similarly Brief, Buttram and Dukerich (2001) have identified the processes under which corruption becomes a collective practice in organizations. Once the key elements of a corrupt organisational climate are established through goal emphasis, means emphasis and rewards orientation and supported by organisational elements of structure, roles and norms, corrupt behaviours become a collective corporate practice (Brief, et al. 2001)

A second aspect to the normalisation process which involves rationalisation of corrupt practice. Rationalizations capitalize on the complexity ambiguity and dynamism of the situation. Actions that appear corrupt in hindsight may have been taken on an adhoc basis, under pressure or with incomplete information. Once initial acts of corruption occur they tend to gain momentum, as the organization tends to count on the rewards of the action ( $\mathrm{Li}$ and Quang, 2007). With the decision already made, it becomes easier to perpetuate the acts rather than to stop them. According to Ashford and Anand (2003) there are a range of factors that individuals use to rationalise corrupt behaviour. The denial of responsibility involves the actors engaged in corrupt behaviours perceiving that they have no other choice than to participate in such activities, that it is a necessary aspect of their activities. Further individuals rationalize that they are entitled to indulge in corrupt behaviours because of their accrued credits (time and effort) in their jobs for which they are not directly financially renumerated.

When a corrupt practice is embedded in an organisation, Anand, Ashforth, and Joshi, (2005) suggest that the desire for group acceptance reduces individual concerns, which leads to acceptance of and the development of a social cocoon. Once formed, corruption may be facilitated through the following stages:

(1) The organization's leadership and longer term staff (veterans), role model the corrupt behaviour.

(2) Individuals are encouraged to affiliate, bond with and develop desires to identify with, emulate, and please veterans and leaders.

(3) Strong and consistent information and ideological statements are made so that corrupt acts are seen in a positive light.

(4) Individuals are encouraged to attribute any misgivings they may have to their own shortcomings (particularly naiveté) rather than to what is being asked of them.

Systematic corruption was linked to the collective processes of organisations reflected in the structure, culture and social practices of the organisation (Palmer 2008). Spicer (2009) in an analysis of the literature on normalisation of corruption affirms the research of Palmer (2008) and Ashford and Anand (2003) amongst others that organisational systems, culture and socialisation processes support the take up and embededness of corrupt practices in organisations.

In terms of managers exercising individualist ethical practices against corrupt collective organisational practices, this would be difficult to maintain given the pressures to demonstrate behavioural norms and also to secure business through these corrupt methods. The issue of whistle blowing (Donaldson \& Werhane, 1999; Shaw \& Barry, 1998; Trevino \& Nelson, 1999) also becomes an issue for managers. Whistleblowers may experience dissonance between their personal values and what is expected of them from organisational cultural and systemic norms of business practice (Spicer, 2009). Experience suggests that the protection offered to the whistle blower in outing corrupt business practice may be totally inadequate (Lewis, 2008).

There is a confluence of potential factors acting on modern managers that may result in corrupt practice inclusive of accepting or issuing bribes (Vogl, 1998). They are present at the micro level of the individual manager and his/her propensity towards corrupt influence, at the meso level of the organization itself in terms of the cultural practices and norms of corporate behaviours and finally at the macro level of external influences that may press for illicit favours or bribes. 


\subsection{Research method and purpose of the study}

A survey instrument was developed to analyse the attitudes of mid level managers to concepts in business ethics and issues related to corruption and in particular practices of bribery. Following University ethics approval the survey forms were distributed to the selected sample of mid level managers and the anonymous returned surveys became the sample data set (Sarantakos, 1993). The survey instrument was designed with closed questions, open ended qualitative questions and a series of five point likert scale questions to surface attitudes to the following:

- awareness of unethical practices in your organisations;

- attitudes to concepts such as honesty, integrity, fairness and the ability to make ethical decisions;

- views on bribery and corruption;

- reaction to being offered a bribe;

- reaction to being asked for a bribe;

- what you would do if aware of unethical practices in your organisation;

- If you were asked to undertake unethical practices and it became public, what would you expect your organisation or manager to do;

- What is your view about the role of Governments in controlling bribery and corruption.

A total of 112 managers from a diverse range of private and public companies located in Australia and operating trans-nationally represented the population for the survey. A response rate of $60 \%$ was achieved. The following section of the paper presents the key findings to the issue of what managers know and do in relation to bribery in particular and their attitudes towards the larger context issues of corruption and concepts underpinning ethics in business.

\subsection{Discussion and findings}

From a population of 112 managers 67 respondents completed an anonymous on line survey form covering issues on business ethics practices, experience of bribery and attitudes towards corruption as outlined in section 2 above. Reviewing the responses the following results were obtained.

\begin{tabular}{|l|l|l|l|l|l|}
\hline $\begin{array}{l}\text { Matrix } 4.1 \\
\text { Question Stem } \\
\begin{array}{l}\text { Concepts such as honesty, integrity, fairness } \\
\text { and the ability to make ethical decisions }\end{array}\end{array}$ & $\begin{array}{l}\text { Response } \\
\text { Strongly } \\
\text { Agree }\end{array}$ & $\begin{array}{l}\text { Response } \\
\text { Agree }\end{array}$ & $\begin{array}{l}\text { Response } \\
\text { Neither } \\
\text { Agree Nor } \\
\text { Disagree }\end{array}$ & $\begin{array}{l}\text { Response } \\
\text { Disagree }\end{array}$ & $\begin{array}{l}\text { Response } \\
\text { Strongly } \\
\text { Disagree }\end{array}$ \\
\hline $\begin{array}{l}\text { - are not necessary and a possible } \\
\text { impediment to effective business decision } \\
\text { making. }\end{array}$ & $11.1 \%$ & $9.5 \%$ & $27.8 \%$ & $32.8 \%$ & $18.8 \%$ \\
\hline $\begin{array}{l}\text { - are learned early in life and cannot be } \\
\text { changed in adulthood. }\end{array}$ & $12 \%$ & $11.9 \%$ & $31.3 \%$ & $41.9 \%$ & $2.9 \%$ \\
\hline $\begin{array}{l}\text { - are an important managerial capability that } \\
\text { most managers have already developed. }\end{array}$ & $10.5 \%$ & $41.9 \%$ & $23.8 \%$ & $17.9 \%$ & $5.9 \%$ \\
\hline $\begin{array}{l}- \text { are important managerial capabilities that } \\
\text { need to be learned and understood. }\end{array}$ & $73.6 \%$ & $14.8 \%$ & $5.9 \%$ & $2.8 \%$ & $2.9 \%$ \\
\hline
\end{tabular}

To the question "Have you ever been aware of unethical practices in your organisation?" Seventy eight per cent of respondents confirmed that they had experienced unethical practices, whilst $22 \%$ responded that they had no experience of unethical practice in their organization. Although the nature of type of practice and consistency/regularity of practice was not accounted for, with a further open ended question in the survey to identify degree of the unethical practice, the high response to 
experience of the practice is of concern. This would indicate that for this sample unethical practice is a common feature encountered in most contemporary organisations by mid level practising managers.

Matrix 4.1 outlines responses to the next series of questions regarding attitudes to concepts of honesty, integrity, fairness and the ability to make ethical decisions. Analysing the responses in Matrix 4.1, over $50 \%$ of respondents disagreed or strongly disagreed with the statement that, concepts such as honesty, integrity, fairness and the ability to make ethical decisions are not necessary and a possible impediment to effective business decision making. Again about $62 \%$ of respondents agreed or strongly agreed that the concepts were an important capability that most managers have already developed. This is an interesting response given that $77 \%$ of the respondents were aware of unethical practices in their own organisations. This calls into question the level of understanding of ethical business practice and level of sophistication of practice in the organisational setting beyond minimum codes (Donaldson \& Werhane, 1999; Shaw \& Barry, 1998).

In the next response over $85 \%$ of respondents agreed or strongly agreed that the concepts of honesty, integrity, fairness and the ability to make ethical decisions are important managerial capabilities and need to be learned and understood. Clearly the from the indication of experience of unethical practice and the response here there appears to be considerable need to develop understanding of business ethics concepts and practice.

\begin{tabular}{|l|l|l|l|l|l|}
\hline $\begin{array}{l}\text { Matrix 4.2 } \\
\text { Question Stem }\end{array}$ & $\begin{array}{l}\text { Response to } \\
\text { Strongly } \\
\text { Agree } \\
\text { Which statement best describes your views } \\
\text { on bribery and corruption }\end{array}$ & $\begin{array}{l}\text { Response } \\
\text { to Agree }\end{array}$ & $\begin{array}{l}\text { Response } \\
\text { to Neithe } \\
\text { Agree Nor } \\
\text { Disagree }\end{array}$ & $\begin{array}{l}\text { Response } \\
\text { to Disagree }\end{array}$ & $\begin{array}{l}\text { Response } \\
\text { to Strongly } \\
\text { Disagree }\end{array}$ \\
\hline $\begin{array}{l}\text { - a business practice that whilst undesirable } \\
\text { is necessary in many situations }\end{array}$ & $76.5 \%$ & $12.3 \%$ & $2.9 \%$ & $1.4 \%$ & $6.9 \%$ \\
\hline $\begin{array}{l}- \text { a practice that is wrong and adds cost to } \\
\text { the organisation }\end{array}$ & $23.3 \%$ & $51.8 \%$ & $7.5 \%$ & $2.9 \%$ & $14.5 \%$ \\
\hline $\begin{array}{l}- \text { a practice that is not part of normal } \\
\text { business practice in my country but } \\
\text { necessary in others }\end{array}$ & $22.1 \%$ & $20.0 \%$ & $16.4 \%$ & $17.9 \%$ & $23.6 \%$ \\
\hline $\begin{array}{l}- \text { a matter of choice for managers and } \\
\text { business }\end{array}$ & $11.9 \%$ & $7.4 \%$ & $26.8 \%$ & $17.9 \%$ & $36.0 \%$ \\
\hline $\begin{array}{l}\text { a practice that exposes individual } \\
\text { managers to risk }\end{array}$ & $33.3 \%$ & $30.3 \%$ & $18.2 \%$ & $9.1 \%$ & $9.1 \%$ \\
\hline
\end{tabular}

Matrix 4.2 outlines responses to a series of questions on bribery and corruption. Nearly $90 \%$ of respondents agreed or strongly agreed with the statement that bribery and corruption is a business practice whilst undesirable is necessary in many situations. This would imply that respondents consider bribery and corruption as, 'necessary evils' in given situations, as opposed to rejecting the concepts outright. The level of response would confirm the rationale for corporations taking part in corrupt practices posited by Carmichael (1995). This also affirms the earlier findings of Bowman and Gilligan (2007) that a substantial majority of respondents to their survey agreed that corruption was damaging, was also inevitable, and increasing in Australia.

The next response is an interesting contrast with the first response. Nearly $75 \%$ of respondents agreed that bribery and corruption are wrong and add costs to the organisation. The responses confirm awareness by managers that the practices are 'wrong'. Forty two percent of respondents agreed or strongly agreed that the issue is not part of normal business practice in my country but necessary in others. Forty two per cent also disagreed/strongly disagreed with the statement. This may imply that 
for these managers their view towards bribery and corruption is that such practices are not part of normal business practice at home nor are they necessarily part of business practice abroad.

The next response group indicated that $19 \%$ of respondents agreed that bribery and corruption were a matter of choice for managers and business, whereas 54\% disagreed that it was a matter of choice. Clearly the managers in this sample view the practice of bribery and corruption as more of an expectation imposed upon them to pursue acts of bribery and corruption rather than exercise their own choice in such matters. This has some connection to the work of Ashford and Anand (2003) in rationalising the processes of corruption and bribery. Interestingly for the final response group $64 \%$ of respondents agree that bribery and corruption is a practice that exposes individual managers to risk. The managers are therefore are aware that these practices entail 'risk'.

From this group of responses the majority of managers in this sample are aware that bribery and corruption are practices that are wrong, place managers at risk, are undesirable but necessary sometimes and managers had little choice in engaging in these practices. This to some extent is confirmed by research into the normalisation of corruption in organisations (Spicer, 2009; Palmer, 2008; Ashford and Anand, 2003) which indicates that corrupt practices can become behavioural norms within the culture and systems of an organisation over time.

\begin{tabular}{|l|l|l|l|l|l|}
\hline $\begin{array}{l}\text { Matrix } 4.3 \\
\text { Question Stem } \\
\text { Which statement best describes how you } \\
\text { would react to being offered a bribe }\end{array}$ & $\begin{array}{l}\text { Response to } \\
\text { Strongly } \\
\text { Agree }\end{array}$ & $\begin{array}{l}\text { Response } \\
\text { to Agree }\end{array}$ & $\begin{array}{l}\text { Response } \\
\text { to Neither } \\
\text { Agree Nor } \\
\text { Disagree }\end{array}$ & $\begin{array}{l}\text { Response } \\
\text { to Disagree }\end{array}$ & $\begin{array}{l}\text { Response } \\
\text { to Strongly } \\
\text { Disagree }\end{array}$ \\
\hline $\begin{array}{l}\text { I would politely decline indicating that it } \\
\text { was not necessary }\end{array}$ & $76.5 \%$ & $12.3 \%$ & $2.9 \%$ & $1.4 \%$ & $6.9 \%$ \\
\hline $\begin{array}{l}\text { I would seek advice from my } \\
\text { manager/organisation as to the appropriate } \\
\text { action }\end{array}$ & $23.3 \%$ & $51.8 \%$ & $7.5 \%$ & $2.9 \%$ & $14.5 \%$ \\
\hline $\begin{array}{l}\text { If the bribe were of minimal value I would } \\
\text { accept so as to not offend. }\end{array}$ & $6.1 \%$ & $3.3 \%$ & $28.4 \%$ & $8.9 \%$ & $53.3 \%$ \\
\hline $\begin{array}{l}\text { I would accept the bribe if refusing were to } \\
\text { jeopardize gaining the business }\end{array}$ & $30.3 \%$ & $10.0 \%$ & $7.0 \%$ & $24.0 \%$ & $28.7 \%$ \\
\hline $\begin{array}{l}\text { I would accept the bribe if refusing were to } \\
\text { jeopardize gaining the business and report it } \\
\text { to my organisation. }\end{array}$ & $8.0 \%$ & $8.6 \%$ & $26.7 \%$ & $23.1 \%$ & $33.6 \%$ \\
\hline
\end{tabular}

Matrix 4.3 considers behaviours of managers in relation to being offered a bribe. The first group of responses indicated that $89 \%$ of the respondents agreed/strongly agreed that they would politely decline indicating that it was not necessary. Some $8 \%$ of respondents though indicate that they disagree with the statement of reaction to being offered a bribe as I would politely decline indicating that it was not necessary. The situation changes with the next response group. $74 \%$ of the respondents agreed/strongly agreed that on being offered a bribe that they would seek advice from my manager/organisation as to the appropriate action. With the previous response in which the manager alone makes the choice to politely decline the bribe $77 \%$ strongly agreed with the statement, yet only $24 \%$ of managers strongly agree with seeking advice from a manager or the organisation as to the appropriate action. It seems that managers are more comfortable determining refusal of a bribe than referring the bribe to their manager or organisation by a ratio of 3 to 1 . In the next response group the interesting feature to the question to accept a bribe, If the bribe were of minimal value I would accept so as to not offend, the interesting result was not so much the $53 \%$ who strongly disagreed as was the $29 \%$ who neither agreed nor disagreed. This would indicate some equivocation regarding the nature of the bribe - perhaps the minimal value and not offending aspects highlighted in the statement. Cultural 
issues such as eastern face saving sensitivities and western embarrassment may impact responses here (Hofstede, 2001; Hofstede \& Hofstede, 2005).

The last two response groups display an interesting outcome. $40 \%$ of respondents agree they would accept the bribe if it were to jeopardize gaining the business, yet only $17 \%$ of respondents agree they would accept the bribe if it were to jeopardize gaining the business and report it to my organisation. The implication here is that some respondents would accept a bribe if it were to jeopardize gaining the business but are not comfortable reporting it to their business. Again the level of neither agree nor disagree responses to declaring the bribe to the business rose to $27 \%$ from $7 \%$ for the previous question an almost fourfold increase. Again managers seem uncomfortable with declaring/discussing the bribery activity with their organisation. One contention might be the managers distrust the actions of organisation due to the propensity for corruption by members within the organisation.

\begin{tabular}{|l|l|l|l|l|l|}
\hline $\begin{array}{l}\text { Matrix 4.4 } \\
\text { Question Stem } \\
\text { Which statement best describes how you } \\
\text { would react to being asked for a bribe }\end{array}$ & $\begin{array}{l}\text { Response to } \\
\text { Strongly } \\
\text { Agree }\end{array}$ & $\begin{array}{l}\text { Response } \\
\text { to Agree }\end{array}$ & $\begin{array}{l}\text { Response } \\
\text { to Neither } \\
\text { Agree Nor } \\
\text { Disagree }\end{array}$ & $\begin{array}{l}\text { Response } \\
\text { to } \\
\text { Disagree }\end{array}$ & $\begin{array}{l}\text { Response } \\
\text { to } \\
\text { Strongly } \\
\text { Disagree }\end{array}$ \\
\hline $\begin{array}{l}\text { I would decline on a personal basis } \\
\text { believing bribery to be wrong }\end{array}$ & $78.1 \%$ & $7.8 \%$ & $7.8 \%$ & $1.6 \%$ & $4.7 \%$ \\
\hline $\begin{array}{l}\text { I would decline if my company had a strict } \\
\text { policy on bribery }\end{array}$ & $24.3 \%$ & $39.4 \%$ & $15.2 \%$ & $7.5 \%$ & $13.6 \%$ \\
\hline $\begin{array}{l}\text { I would offer a bribe if it was of minimal } \\
\text { value and would facilitate the process }\end{array}$ & $10.3 \%$ & $1.5 \%$ & $17.6 \%$ & $23.5 \%$ & $47.1 \%$ \\
\hline $\begin{array}{l}\text { I would consult with my manager and } \\
\text { follow his/her advice }\end{array}$ & $24.7 \%$ & $16.1 \%$ & $24.7 \%$ & $28.4 \%$ & $9.9 \%$ \\
\hline $\begin{array}{l}\text { I would find a way to not pay the bribe } \\
\text { directly such as arranging for an } \\
\text { intermediary to handle such matters and } \\
\text { have them invoice my organisation for } \\
\text { administration/management fees }\end{array}$ & $16.4 \%$ & $6.0 \%$ & $17.9 \%$ & $25.4 \%$ & $34.3 \%$ \\
\hline
\end{tabular}

Matrix 4.4 deals with questions relating to managers views on offering or being asked to provide bribes. To the statement $I$ would decline on a personal basis believing bribery to be wrong, $86 \%$ of respondents agreed. To the second statement I would decline if my company had a strict policy on bribery, presents a shift in responses $64 \%$ agreed with the statement whilst the disagreed/strongly disagreed response of $21 \%$ was four times the response rate to the previous statement regarding decline on a personal basis believing bribery to be wrong. It would appear that managers value their own personal ethics above company policies on matters of corruption. Some $12 \%$ of managers agreed or strongly agreed that they would offer a bribe if it was of minimal value and would facilitate the process. This is consistent with the response of $10 \%$ agreed or strongly agreed to the Matrix 4.3 statement regarding accepting bribes - If the bribe were of minimal value I would accept so as to not offend. It would seem that about $10 \%$ of the managers in this sample are prepared to receive a bribe of minimal value and offer a bribe of minimal value. It should be noted that $71 \%$ disagreed or strongly disagreed with the proposition that they would offer a bribe if it was of minimal value and would facilitate the process.

The statement I would consult with my manager and follow his/her advice on being asked for a bribe throws up considerable changes to previous responses. Forty one per cent of respondents agreed or strongly agreed to the statement, $25 \%$ neither agreed nor disagreed, and 38\% disagreed or strongly disagreed. Again as with the final question in Matrix 4.3 on advising the organisation of the bribery offer, alters the dynamic of the situation. The results imply mixed perceptions regarding consulting with a manager. 
For the final statement in matrix 4.4 I would find a way to not pay the bribe directly such as arranging for an intermediary to handle such matters and have them invoice my organisation for administration/management fees, $16 \%$ of respondents indicated strongly agree, $6 \%$ indicated agree, $18 \%$ neither agree nor disagree, $26 \%$ disagree and $34 \%$ strongly disagree with the statement. Sixty per cent of the managers are in disagreement with this process however $24 \%$ do agree or strongly agree with the process. Although a majority of respondents reject the third party approach to delivering the bribe a quarter of respondents as a reasonable reaction to being asked for a bribe.

\begin{tabular}{|l|l|l|l|l|l|}
\hline $\begin{array}{l}\text { Matrix 4.5 } \\
\text { Question Stem } \\
\text { If you were aware of unethical practices in } \\
\text { your organisation would you: }\end{array}$ & $\begin{array}{l}\text { Response to } \\
\text { Strongly } \\
\text { Agree }\end{array}$ & $\begin{array}{l}\text { Response } \\
\text { to Agree }\end{array}$ & $\begin{array}{l}\text { Response } \\
\text { to Neither } \\
\text { Agree Nor } \\
\text { Disagree }\end{array}$ & $\begin{array}{l}\text { Response } \\
\text { to } \\
\text { Disagree }\end{array}$ & $\begin{array}{l}\text { Response } \\
\text { to } \\
\text { Strongly } \\
\text { Disagree }\end{array}$ \\
\hline Do nothing & $13.9 \%$ & $11.1 \%$ & $15.3 \%$ & $12.5 \%$ & $47.2 \%$ \\
\hline $\begin{array}{l}\text { Report the action to my manager or superior } \\
\text { irrespective of an anonymous reporting } \\
\text { system }\end{array}$ & $56.2 \%$ & $15.1 \%$ & $10.9 \%$ & $9.6 \%$ & $8.2 \%$ \\
\hline $\begin{array}{l}\text { Report the action ONLY if the organisation } \\
\text { has an anonymous reporting system }\end{array}$ & $23.5 \%$ & $30.9 \%$ & $20.6 \%$ & $8.8 \%$ & $16.2 \%$ \\
\hline $\begin{array}{l}\text { Report the action to an external body such } \\
\text { as Ombudsperson or Government } \\
\text { Commission against corruption }\end{array}$ & $15.5 \%$ & $26.2 \%$ & $23.8 \%$ & $20.2 \%$ & $14.3 \%$ \\
\hline $\begin{array}{l}\text { Report the matter anonymously to a } \\
\text { newspaper or TV journalist }\end{array}$ & $10.3 \%$ & $4.4 \%$ & $7.4 \%$ & $25.0 \%$ & $52.9 \%$ \\
\hline
\end{tabular}

Referring to responses in matrix 4.5 , about $60 \%$ of respondents disagree or strongly disagree with the proposition that If you were aware of unethical practices in your organisation they would do nothing. However, $25 \%$ of respondents agree or strongly agree that Do nothing is the preferred course of action. This would imply that for some managers the issue of alerting senior management to unethical practices in an organisation remains a sensitive issue. Lewis (2008) found that in the UK over a ten year period protection for whistle blowers was inadequate.

For the next response statement, Report the action to my manager or superior irrespective of an anonymous reporting system $71 \%$ of respondents agreed or strongly agreed with the statement whilst $18 \%$ disagreed or strongly disagreed with it. In respect of the next statement Report the action ONLY if the organisation has an anonymous reporting system 54\% agreed or strongly agreed whilst $25 \%$ disagreed or strongly disagreed with it. Analysing the responses to these last two statements together, there would seem to be a counterintuitive situation here. Fewer respondents confirmed that they would report the unethical practice ONLY if an anonymous reporting system operated compared to directing the report straight to a manager or supervisor irrespective of an anonymous reporting system. Again there could be a lack of trust with the organisation's systems and processes to be anonymous. The higher proportion of respondents indicated disagree or strongly disagree at $25 \%$ and neither agree nor disagree at $20 \%$ would indicate that more managers perceived an anonymous reporting system less attractive than reporting directly to their manager or supervisor.

With reference to external reporting of the unethical organisational practices, $42 \%$ agreed or strongly agreed that reporting the action to an external body such as an Ombudsperson or Government Commission against corruption was a correct course of action whereas $24 \%$ neither agreed nor disagreed with the proposition and $34 \%$ disagreed or strongly disagreed with the course of action. It would appear that managers prefer to report unethical practices internally to managers and supervisors 
( $71 \%$ of respondents agreed/strongly agreed) than reporting to external corruption authorities $(42 \%$ of respondents agreed/strongly agreed).

Faith in external reportage by newspaper or TV journalists was also low as a medium to report corruption by the manager sample group. $78 \%$ of respondents disagreed or strongly disagreed with the proposition to Report the matter anonymously to a newspaper or TV journalist. Only $15 \%$ of respondents agreed or strongly agreed that this was a preferable course of action.

\begin{tabular}{|l|l|l|l|l|l|}
\hline $\begin{array}{l}\text { Matrix 4.6 } \\
\text { Question Stem } \\
\text { If you were asked to undertake } \\
\text { unethical practices and it became } \\
\text { public, would your organisation or } \\
\text { manager: }\end{array}$ & $\begin{array}{l}\text { Response to } \\
\text { Strongly } \\
\text { Agree }\end{array}$ & $\begin{array}{l}\text { Response } \\
\text { to Agree }\end{array}$ & $\begin{array}{l}\text { Response } \\
\text { to Neither } \\
\text { Agree Nor } \\
\text { Disagree }\end{array}$ & $\begin{array}{l}\text { Response } \\
\text { to } \\
\text { Disagree }\end{array}$ & $\begin{array}{l}\text { Response } \\
\text { to } \\
\text { Strongly } \\
\text { Disagree }\end{array}$ \\
\hline $\begin{array}{l}\text { Support my actions and assume } \\
\text { responsibility }\end{array}$ & $19.1 \%$ & $13.2 \%$ & $16.2 \%$ & $5.9 \%$ & $45.6 \%$ \\
\hline $\begin{array}{l}\text { Publicly acknowledge that I was directed to } \\
\text { undertake the action }\end{array}$ & $14.9 \%$ & $13.4 \%$ & $19.4 \%$ & $29.9 \%$ & $22.4 \%$ \\
\hline $\begin{array}{l}\text { Privately acknowledge that I was directed to } \\
\text { undertake the action and provide assistance }\end{array}$ & $25.0 \%$ & $13.2 \%$ & $30.9 \%$ & $17.7 \%$ & $13.2 \%$ \\
\hline Deny any knowledge of my actions & $28.4 \%$ & $26.9 \%$ & $8.9 \%$ & $16.4 \%$ & $19.4 \%$ \\
\hline $\begin{array}{l}\text { Most likely to ask me to resign or dismiss } \\
\text { me }\end{array}$ & $47.1 \%$ & $11.8 \%$ & $10.3 \%$ & $13.2 \%$ & $17.6 \%$ \\
\hline
\end{tabular}

The final matrix 4.6 refers to managers perceptions of how their organisation would respond to if unethical practices which the organisation had instructed the managers to participate in became public. Responses to the first statement that the organisation or manager would Support my actions and assume responsibility indicated that $19 \%$ of respondents strongly agreed and $13 \%$ agreed with the statement, 16\% neither agreed nor disagreed, $6 \%$ disagreed and $46 \%$ strongly disagreed with the statement. Managers seemed to disagree more with the statement with a significant level of strong disagreement. This would indicate a perceived lack of trust in their supervisor to take responsibility for instructing the manager to act unethically. For the next statement Publicly acknowledge that I was directed to undertake the action $15 \%$ strongly agreed and $13 \%$ agreed with the statement, $20 \%$ neither agreed nor disagreed, $30 \%$ disagreed and $23 \%$ strongly disagreed with the statement. $53 \%$ of managers disagreed that their organisation or manager would publicly acknowledge that they as a manager were directed to undertake the unethical actions. Again for the majority of managers there is little trust in the organisation supporting the individual manager.

To the next statement there is some change to the responses in that the admission by the organisation is private and the organisation offers support. To the statement, Privately acknowledge that I was directed to undertake the action and provide assistance, $25 \%$ of respondents strongly agreed, $13 \%$ agreed, $31 \%$ neither agreed nor disagreed with the statement, $18 \%$ disagreed and $13 \%$ strongly agreed with the statement. There is no clear indication of preference $38 \%$ agree/strongly agree, $31 \%$ are ambivalent and $31 \%$ disagree/strongly disagree with managing the situation internally. Again there may be issues of a lack of trust within a corrupt practising organisation in how the internal assistance will be managed.

The next statement is very clear in its responses; $55 \%$ of respondents strongly agree or agree that the manager's organisation or manager would, Deny any knowledge of my actions. Only $9 \%$ neither agree nor disagree, $16 \%$ disagree and $20 \%$ strongly disagree with the statement. A significant proportion of 
managers perceive that their organisation or manager would sacrifice them even though the unethical action was sanctioned by the organisation. Responses for the final statement Most likely to ask me to resign or dismiss me indicated that $47 \%$ of respondents strongly agreed and $12 \%$ agreed with the statement, $10 \%$ neither agreed nor disagreed, $13 \%$ disagreed and $18 \%$ strongly disagreed with the statement. A high proportion of managers (59\%) expect to be dismissed are asked to resign under circumstances where the unethical action was dictated by senior management. Thirty one per cent, however, disagree or strongly disagree with the proposition that an organisationally orchestrated unethical situation should lead to the individual manager's resignation or dismissal.

\subsection{Conclusion}

This paper has presented a review of literature that suggests that the causes of bribery and corruption are numerous and that organisations can be prone to development of collective cultures in which corruption may become normalized. Given the opportunities for corrupt behaviour to infiltrate organizations particularly through, processes of rationalization, socialization and institutionalization (Ashforth and Anand, 2003; Spicer, 2009), the findings from this survey indicating awareness of and propensity for unethical business practice are not surprising. The further literature in the field of corruption and bribery applied in the discussion of findings for the present article established a stark frame against which the primary data from the survey results was contrasted and assessed.

Based on the survey responses from a sample of mid level managers, the following conclusions have been be drawn:

- Managers have a confused and conflicting awareness of critical concepts in business ethics and ethics per se.

- Managers continue to be confronted with ethical dilemmas in their business practice.

- Managers appear to distrust external agencies and the broader internal organizational systems to address organisational unethical transgressions but show a greater propensity to trust their internal senior management for advice and support.

- Managers remain ill equipped to resolve potential and actual bribery issues in their industries.

- Based upon the responses from this sample of managers, there appears to be evidence that organisations though not wholly corrupt certainly display evidence of unethical practices. A high proportion of managers $(78 \%)$ indicated that they had experienced unethical practices in their organization. Clearly, there is still much work in developing business ethics in applied practice within the corporate environment.

Further research issues are clearly raised by this paper. In particular some of the research questions could be refined to gain a deeper level of insight. Qualitative face to face semi structured interviews to supplement the surveys could provide greater insight to manager perceptions and practices. Stratified sampling of the data by gender and nationalities could provide further dimensionality to the responses and insights from them into current business ethics practice in modern organizational settings. The issue of managerial trust in organisations to develop a transparent culture to surface unethical practice as well as support ethical practice is also are worthy of research effort.

\section{References}

Alatas, S.H. 1999, Corruption and the Destiny of Asia, Prentice Hall, Selangor.

Ampratwum. F.E 2008. 'The fight against corruption and its implications for development in developing and transaction economies', Journal of Money Laundering Control, Vol.10, No. 1, pp. 76-87

Anand, V., Ashforth B.E. and Josji M. 2005. "Business as usual: The acceptance and perpetuation of corruption in organizations" Academy of Management Executive, Vol. 19, no. 4, pp 9-23

Andenas, M. 1995, 'Illicit Payments Abroad', Journal of Financial Crime, Vol. 3, No. 1. pp. 59 - 61. 
Apke, T. 2001. 'Impact of OECD Convention anti-bribery provisions on international companies', Managerial Auditing Journal, Vol. 16, Issue. 2, pp. 30-45

Ashforth, B.E, and Anand, V, 2003. 'The normalization of corruption in organization', Research in Organizational Behavior, Vol. 25, pp.1-25

Batabyal, A. A and Yoo, S. J. 2007. 'Corruption, Bribery, and Wait Times in the Public Allocation of Goods in Developing Countries', Review of Development Economics, Vol. 11, No.3, pp. 507517.

Beets, D. 2004. "Understanding the demand-side issues of international corruption", Journal of Business Ethics, vol. 57, no. 1, pp. 65-81.

Bowman, D. and Gilligan, G. 2007. 'Public awareness of corruption in Australia.' Journal of Financial Crime, Vol. 14 No. 4, pp. 438-452.

Brief, A.P, Buttram, R.T, and Dukerich, J.M. 2001. 'Collective corruption in the corporate world: Toward a process model.' In M.E. Turner (Ed.). Groups at Work: Theory and Research, pp 471 - 499, Erlbaum, Mahwah, N.J.

Carmichael S. 1995, Business ethics: The new bottom line, London.

Davies, H., Leung, T., Luk, S. and Wong, Y. 1995. 'The benefits of Guanxi: The value of relationshipsin developing the chinese market'. Industrial Marketing Management, Vol. 24, No. 3, pp. 207-214.

Davis, J. and Ruhe, A. 2003. 'Perceptions of country corruption: antecedents and outcomes', Journal of Business Ethics, Vol. 43, No. 4, pp. 275-288..

Dion, M. 2010. 'What is corruption corrupting? A philosophical viewpoint.' Journal of Money Laundering Control, Vol. 13, No. 1, pp. 45-54.

Donaldson, T, and Dunfee, T.W. 1999a, 'When ethics travel: the promise and peril of global business ethics'. California Management Review , pp.45-63.

Donaldson, T, and Dunfee, T.W. 1999b, Ties that bind: A Social Contracts Theory of Business Ethics. Harvard Business School Press, Boston, M.A.

Donaldson T. \& Werhane, P.H. 1999, Ethical Issues in Business, $6^{\text {th }}$ Edn. Prentice Hall, Upper Saddle, New Jersey.

D’Souza, C 2003. 'An Inference of Gift-Giving Within Asian Business Culture', Asia Pacific Journal of Marketing and Logistics, Vol 15, No. 1, pp 27-38

Feng, Y, 2000. 'Corruption: Main Dangers to Economic and Political Stability and Root Causes', Journal of Money Laundering Control, Vol. 4, No. 1, p. 44-50.

Goldsmith, A.A. 1995, 'Democracy, property rights and economic growth', Journal of Development Studies, Vol. 32, No. 2, pp. 157-175.

Goudie, A.W. and Stasavage, D. 1998. A framework for the analysis of corruption', Journal of Crime, Law \& Social Change, Vol 29, No. 2-3, pp. 113-159.

Graham, T 2000. 'Legal and Other Issues Raised by Grand Corruption', Journal of Financial Crime, Vol. 7, No. 4, pp. 324-329.

Gray, C.W. and Kaufmann, D. 1998. 'Corruption and development', Finance and Development, March, pp. 7-10.

Halter, M.V., Coutinho de Arruda, M.C. and Halter, R.B. 2009. 'Transparency to reduce corruption.' Journal of Business Ethics, Vol. 84, pp. 373-385.

Hess, D.W. 2004. 'Catalyzing corporate commitment to combating corruption.' Journal of Business Ethics, Vol. 88, pp. 781-790.

Hess, D.W. and Dunfee, T.W. 2003. 'Taking responsibility for bribery.' In Cornell International Law Journal, Vol. 33, pp. 593-626.

Hess, D.W. and Dunfee, T.W. 2000. 'Fighting corruption: A principle approach.' Cornell International Law Journal, Vol. 33, pp. 593-626.

Hofstede G 2001, Cultures Consequences: Comparing values, behaviours, institutions and organisations across nations, $2^{\text {nd }}$ Edn. Sage Publications, Thousand Oaks, CA.

Hofstede G., and Hofstede G. 2005, Cultures and Organisations; Software of the mind. New York, McGraw Hill. 
Kaufmann, D. 1997. 'Corruption: the facts', Foreign Policy, No.107, Summer, pp.113-131.

Kauffmann, D. and Wei, S. 1998. 'Does "Grease Money" speed up the wheels of commerce?' American Economic Association, January, Chicago, pp 1-17

Kayes, D.C. 2006. 'Organizational corruption as theodicy.' Journal of Business Ethics, Vol. 67, PP. $51-62$.

KPMG, 2008. 2008 Fraud Survey, KPMG, Australia and New Zealand.

Ksenia, G, 2008. 'Can corruption and economic crime be controlled in developing countries and if so, is it cost-effective?' Journal of Financial Crime, Vol. 15, No. 2, pp. 222-233.

Lewis, D. 2008. 'Ten years of public interest disclosure legislation in the UK:

Are whistleblowers adequately protected?' Journal of Business Ethics, Vol. 82. pp. 497-507.

Lewis R.D, 2006, When culture collide: leading across cultures, $3^{\text {rd }}$ Edn, Nicholas Brearly, Boston.

$\mathrm{Li}$, S, and Ouyang, M, 2007. 'A dynamic model to explain the bribery behavior of firms', International Journal of Management, Vol. 24, pp. 605-618.

Lindgreen, A. 2004. 'Corruption and Unethical Behaviour: Report on a set of Danish guidelines.' Journal of Business Ethics, Vol. 51, Iss. 1, pp. 31-39.

Mauro, P, 1995. 'Corruption and growth', Quarterly Journal of Economics, No. 441 (August), pp 681-712.

MacDonald, A. and Fidler, S 2009. 'Expense furor shakes up U.K. in ways unseen for decades: Public outrage grows when money, not sex, is catalyst for scandal', Wall Street Journal, May 18, p. 16.

McEwan, T. 2001. Managing Values and Beliefs in Organisations, Pearson Education, Harlow England.

Moran R.T., Harris P.R and Moran, S.V 2007, Managing cultural difference: global leadership strategies for the $21^{\text {st }}$ century, Butterworth-Heinemann, Elsevier.

Osbourne, D. 1997, 'Corruption as counter-culture: attitudes to bribery in local and global society', in Rider, B.A.K. (Ed.), Corruption: Enemy Within, Kluwer Law International, London, pp. 9-34.

Oskooee, B, Goswami, M and Gour, G 2005, 'The impact of corruption on the black market premium', Southern Economic Journal, Vol. 71, No. 3, pp 483-493

Palmer, D. 2008. 'Extending the process model of collective corruption', Research in Organization Behavior, Vol. 28. pp. 107-135.

Rose-Ackerman, S. 1999, Corruption and government, Cambridge University Press, UK

Sarantakos, S. 1993, Social Research, Macmillan, South Yarra.

Shaw, W.H. \& Barry, V. 1998, Moral Issues in Business, $7^{\text {th }}$ Edn. Wadsworth Publishing Company, Belmont, CA.

Spicer, A. 2009. 'The normalisation of corrupt business practices: Implications for Integrative Social Contracts Theory (ISCT)', Journal of Business Ethics, Vol. 88 pp 833-840.

Transparency International, 2011a, Frequently asked questions about corruption http://www.transparency.org/news room/faq/corruption faq viewed 30 August 2011.

Transparency International, 2011b, Corruption Perception Index 2010 Report. What is the CPI? http://www.transparency.org/policy research/surveys indices/cpi/2010/in detail viewed 30 August 2011.

Transparency International, 2010. Global Corruption Report, Berlin: Transparency International, Transparency International (TI), Corruption Perceptions Index Rankings, 2010, http://www.transparency.org/policy_research/surveys_indices/cpi/2010/results, viewed June 29, 2011.

Transparency International. 2009, Global Corruption Report, Transparency International, Berlin.Transparency International (TI), 2009, Corruption Perceptions Index Rankings, http://www.transparency.org/policy research/surveys indices/cpi/2009 viewed 5 April 2010.

Transparency International, 2007. Global Corruption Report, Berlin: Transparency International. International, Transparency International (TI), Corruption Perceptions Index Rankings, 2007, http://www.transparency.org/content/download/27256/410704/file/GCB 2007 report en 02 12-2007.pdf, viewed 25 June 2011.

Transparency International, 2006. Bribe payers Index, Berlin: Transparency International. International, Transparency International (TI), Bribe Payers Index, 2006, 
http://www.transparency.org/content/download/9757/71853/file/BPI 2006 Analysis Report 2 70906 FINAL.pdf, viewed 21 June 2011.

Trevino, LK \& Nelson, K. 1999, Managing business ethics: straight talk about how to do it right, $2^{\text {nd }}$ Edn, Wiley and Sons, New York.

United Nations Development Program (UNDP), 2008, Fighting corruption to improve governance, Management Development and Governance Division, UNDP, New York

Vogl, F, 1998, 'The supply side of global bribery' in New Perspectives on Combating Corruption, Transparency International and the Regulatory Reform and Private Enterprise Division of the Economic Development Institute of the World Bank

Von Alemann, U, 2004. 'The unknown depths of political theory: The case for a multidimensional concept of corruption.' Crime, Law and Social Change, Vol. 42. pp. 25-34.

Welsch, H, 2004, 'Corruption, growth and the environment: a cross-country analysis, Environment and Development Economics, Vol. 9, pp. 663-693

Wertheim', W.F. 1965 'Socialogical Aspects of Corruption in Southeast Asia', in S.H. Alatas, 1999. p. 6, Corruption and the Destiny of Asia, Prentice Hall, Selangor.

World Bank. 1997. 'Helping countries combat corruption: The Role of the World Bank', Poverty Reduction and Economic Management, September. 
